\title{
Effect of Seasons x Meteorological Variables on Normal Milk Constituents in Marathwadi Buffaloes
}

\author{
P. M. Kekan ${ }^{1}$, A. K. Wankar ${ }^{1 *}$, S. B. Daware ${ }^{1}$, S. A. Amrutkar ${ }^{2}$ \\ ${ }^{1}$ Department of Veterinary Physiology, ${ }^{2}$ Livestock Farm Complex (LFC), College of \\ Veterinary and Animal Sciences (MAFSU), Parbhnai, M.S, India \\ *Corresponding author
}

\section{Keywords}

Environmental variables, THI,

Milk, Milk

constituents,

Marathwadi

buffaloes

Article Info

Accepted:

14 January 2021

Available Online:

10 February 2021

\section{A B S T R A C T}

The aim of the study was to evaluate the effect of environmental variables and different seasons onnormal milk constituents in Marathwadi buffalo. The milk samples were collected from Marathwadi buffaloes $(n=6)$ fortnightly while, environmental variables i.e., dry bulb temperature (DbT), wet bulb temperature (WbT), wind speed (WS) and solar intensity (LUX) were recorded at a weekly interval (at 14:00 hrs). Non-significant $(\mathrm{P}>0.05)$ variation was observed in milk constituents (fat, protein, SNF, lactose and salt) in summer, winter \& monsoon seasons. Similarly, different environmental variables had no effect on milk constituents during different seasons. Whereas, significantly $(\mathrm{P}<0.01)$ positive correlation was observed between protein and SNF $(r=.986)$, lactose and SNF $(r=.993)$, salt and SNF ( $r=.898)$, lactose and protein $(r=.984)$, salt and protein $(r=.901)$ and salt and lactose ( $r=.901)$, respectively during the study.Therefore, it can be concluded that native breeds have better adaptability to environmental conditions, which is reflected by optimum production and lack of variation in milk constituents in marathwadi buffaloes during different seasons.

\section{Introduction}

Climate change, defined as the long-term misbalance of weather conditions such as temperature, wind and rainfall characteristics of a specific region, is likely to be one of the main challenges that mankind faces during the present century and coming times. Milk protein contains more essential amino acids of high bioavailability, than any other natural food. Solid not fat (SNF) includes non-fatty constituents of milk like protein, minerals and other minor milk constituents. Total solids in milk are the function of different milk constituents. The sum of all the milk constituents measured in percentage result in total solids percentage in milk (Bahiram et al., 2020). When nutritive value of milk protein and other non-fatty constituents especially calcium and vitamins are concerned, SNF content has its own importance.

Indigenous animals are comparatively less affected by heat stress, due to their natural genetic selection. But prolonged high temperatures and humidity constantly challenge the thermoregulation and homeostasis, increasing the energy demands. Thus, less energy is available for productive purposes, leading to decrease in milk production and variation in constituents (Wankar et al., 2020). However, the effects of heat stress have proven to be a great hindrance to their production and optimum productivity in buffaloes and hence require special housing, nutritional or managemental adoptions. The buffalo housing 
should be well ventilated, protected from cold and hot weather (Garkal et al., 2014). Keeping this in view, the present study was panned to evaluate the effect of meteorological variables during different seasons on normal milk constituents in marathwadi buffalo.

\section{Materials and Methods}

The study was carried on six Marathwadi buffaloes (Age > 4 yrs; Body weight $>390 \mathrm{~kg}$ ) at livestock farm complex (LFC), College of Veterinary \& Animal Sciences (MAFSU), Parbhani. All the animals were allowed to graze daily (two hours) after which they were stall fed, milked twice and kept under identical managemental and feeding conditions, with ad libitum water throughout the experiment. The experimental design and procedures were approved by institutional animal ethics committee and were followed stringently throughout the experiment. The data was collected in three seasons (summer, winter and monsoon). According to Kekan et al., (2016) the climate of Marathwada region in wet monsoon (weeks 23 $44,4^{\text {th }}$ June $-4^{\text {th }}$ Nov) period alternates with long rain free cold winter (weeks $45-9,5^{\text {th }}$ Nov $-4^{\text {th }}$ March). While in summers maximum temperature ranges between $40-45^{\circ} \mathrm{C}$ (weeks $10-22,5^{\text {th }}$ March $-3^{\text {rd June). }}$

Milk samples $(50 \mathrm{ml})$ were collected in sterile sample vials at fortnight's interval from all the animals in morning and analyzed within two hours on automatic milk analyzer (Lactosure, Eco model). While, meteorological variables viz. dry bulb temperature (DbT), wet bulb temperature (WbT), wind speed(WS) and solar radiations (LUX)were recorded near the animal shed, every week at $14.00 \mathrm{hrs}$ throughout the experiment.

Dry bulb $\left({ }^{\circ} \mathrm{C}\right)$, wet bulb temperature $\left({ }^{\circ} \mathrm{C}\right)$ and wind speed $(\mathrm{M} / \mathrm{sec})$ were recorded by using fully automatic anemometer (Testo India Pvt Ltd) till maximum readings were reached within one minute. Similarly, solar intensity (LUX) was recorded by using luxmeter (Testo India Pvt Ltd) till maximum reading was achieved. The temperature humidity index (THI) was calculated by using the formula of McDowell (1972).
$\mathrm{THI}=0.72(\mathrm{DbT}+\mathrm{WbT})+40.6$

Where,

THI=Temperature humidity index

DbT $=$ Dry bulb temperature

$\mathrm{WbT}=$ Wet bulb temperature

\section{Statistical analysis}

Data for milk constituents were analyzed by the by one-way analysis of variance (ANOVA) model using SPSS 20.00 software and reported standard error of means (SEM). Correlation between temperature, THI, wind speed, solar radiations and milk constituents were estimated by Pearson's correlation and indicated by $r$ value. Significance was declared at $* \mathrm{P}<0.05$.

\section{Results and Discussion}

The mean values of milk constituent's\% (fat, solid not fat, protein, lactose and salt) during different seasons are presented in Table 1.It is observed that, fat $\%$ was non significantly higher in monsoon, whereas, SNF \%, protein \%, lactose \% and salt $\%$ were non-significantly higher in winter season as compared to summer and monsoon. Fat $\%$ was higher in monsoon and lower in winter but the difference was non-significant. According to Haque et al., (2017) and Cinar et al., (2015), seasons can alter buffalo milk fat $\%$ as there is alteration in nutrient utilization and assimilation during summer season. Fat value variations are expected, as it is the most sensitive milk component to a variety of factors, such as food management, genotype, nutrition, lactation, calving phase and parity (Macedo et al., 2001). Although, the variation for milk fat $\%$ was not significant, it still reflects the seasonal influence in buffaloes in accordance with the past research.

SNF \% were non-significantly $(\mathrm{P}>0.05)$ higher in winter and lower in monsoon as compared to summer season. The mean values obtained in the present study in all the seasons are in close agreement with Sodi et al., (2008) and Balusami (2015), reported in Murrah buffaloes. Cheruiyot et al., (2018) stated that the month of sampling had a significant effect on the content of milk SNF \% 
and Haque et al., (2017) reported milk SNF to be significantly higher during winter season as compared to hot dry and hot humid seasons which supports the present findings. Harris and Bachman (2002) and Mushtaq (2009) opined that milk SNF content also varies with the quality and quantity of the feed. In their study, reducing the concentrate ration below requirements or increasing the roughage and concentrate resulted in decrease and increase, respectively in SNF \% in high yielding cows. Further, the changes that occur in SNF may be primarily attributed to changes in the protein and occasionally to the lactose content of milk.

Table.1 Normal milk constituents in Marathwadi Buffalo during different seasons i.e. winter, summer and monsoon

\begin{tabular}{|l|l|l|l|l|l|}
\hline Season & Fat \% & SNF \% & Protein \% & Lactose \% & Salt \% \\
\hline Winter & 5.86 & 9.25 & 3.34 & 5.05 & 0.70 \\
\hline Summer & 6.43 & 9.17 & 3.32 & 5.00 & 0.70 \\
\hline Monsoon & 6.54 & 9.04 & 3.27 & 4.93 & 0.69 \\
\hline SEM & 0.15 & 0.83 & 0.30 & 0.04 & 0.06 \\
\hline $\boldsymbol{P}$ & 0.14 & 0.59 & 0.63 & 0.54 & 0.00 \\
\hline
\end{tabular}

*SNF=solid not fat; **Superscripts ${ }^{\mathrm{a}, \mathrm{b}, \mathrm{c}}$ indicates significant difference at $\mathrm{P}<0.05$ level within column

Table 2. Correlation between milk constituents and environmental variables in Marathwadi Buffaloes

\begin{tabular}{|l|l|l|l|l|l|l|l|l|l|l|}
\hline & DbT & WbT & WS & LUX & THI & Fat & SNF & Protein & Lactose & Salt \\
\hline DbT & 1 & & & & & & & & & \\
\hline WbT & .207 & 1 & & & & & & & & \\
\hline WS & .088 & -.261 & 1 & & & & & & & \\
\hline LUX & $.501^{* *}$ & -.003 & .218 & 1 & & & & & & \\
\hline THI & $.814^{* *}$ & $.737^{* *}$ & -.094 & $.345^{*}$ & 1 & & & & & \\
\hline Fat & -.055 & .205 & -.290 & .014 & .083 & 1 & & & & \\
\hline SNF & -.014 & .072 & -.191 & .023 & .033 & $.262^{*}$ & 1 & & & \\
\hline Protein & -.015 & .077 & -.201 & .023 & .036 & $.253^{*}$ & $.986^{* *}$ & 1 & & \\
\hline Lactose & -.001 & .078 & -.192 & .039 & .045 & $.267^{* *}$ & $.993^{* *}$ & $.984^{* *}$ & 1 & \\
\hline Salt & -.032 & .088 & -.130 & .026 & .030 & $.215^{*}$ & $.898^{* *}$ & $.901^{* *}$ & $.901^{* *}$ & 1 \\
\hline
\end{tabular}

* Correlation is significant at $\mathrm{P}<0.05$ level, ** Correlation is significant at $\mathrm{P}<0.01$ level

Table.3 Environmental variables during three seasons

\begin{tabular}{|l|l|l|l|l|l|}
\hline Season & DbT $\left({ }^{\mathbf{a}} \mathbf{C}\right)$ & $\left.\mathbf{W b T}^{\mathbf{0}} \mathbf{C}\right)$ & WS(M/sec) & SI (LUX) & THI \\
\hline Winter & $31.87^{\mathrm{a}}$ & $21.93^{\mathrm{a}}$ & $1.86^{\mathrm{b}}$ & 56218.66 & $79.33^{\mathrm{a}}$ \\
\hline Summer & $36.18^{\mathrm{b}}$ & $25.47^{\mathrm{b}}$ & $1.29^{\mathrm{ab}}$ & 60450.00 & $84.98^{\mathrm{b}}$ \\
\hline Monsoon & $31.11^{\mathrm{a}}$ & $25.85^{\mathrm{b}}$ & $0.80^{\mathrm{a}}$ & 47728.50 & $81.61^{\mathrm{a}}$ \\
\hline SEM & 0.54 & 0.47 & 0.13 & 3103.61 & 0.57 \\
\hline $\boldsymbol{P}$ & 0.00 & 0.00 & 0.00 & 0.23 & 0.00 \\
\hline
\end{tabular}

*Superscripts ${ }^{\mathrm{a}, \mathrm{b}, \mathrm{c}}$ indicates significant difference at $\mathrm{P}<0.05$ level within column

$\mathrm{DbT}=$ dry bulb temperature, $\mathrm{WbT}=$ wet bulb temperature, $\mathrm{WS}=$ wind speed, $\mathrm{SI}=$ =solar intensity, $\mathrm{THI}=$ temperature humidity index

The mean values of protein $\%$ did not differed $(\mathrm{P}>0.05)$ in all the seasons. Our values for milk protein are similar to those reported by Pawar et al., (2013) and Cinar et al., (2019). The milk protein concentration shows comparatively high heritability and its quantity in milk is virtually almost constant (Meena et al., 2007). The protein content in buffalo milk is normally around 2.7 - 
5.2\% (Claeys et al., 2014; Patbandha et al., 2015) which correlates well with the average value for the milk samples analyzed in the present study.

The mean values of lactose $\%$ were nonsignificantly higher in winter and summer as compared to monsoon season. The values observed for lactose $\%$ in the present study are in accordance with findings reported by Sales et al (2018) and Zhou et al (2018) in buffaloes. There is close relationship between lactose synthesis and the amount of water drawn into milk, making lactose a stable milk component and which probably maintains secretion rates of lactose and water nearly constant throughout lactation (Pollott 2004).

The salt $\%$ remained stable in summer, winter and monsoon during the study. Similar observation were reported by Wankar et al., (2020) in marathwadi buffaloes and red kandhari cows. They further stated that the process of acclimation and acclimatization to heat stress utilizes both short term and long-term metabolic alterations to maintain electrolyte balance. Animals affected by thermal stress have negative mineral balance as these minerals are lost in sweat and other body fluids.

Correlation between milk constituents and environmental variables are presented in Table 2. Among the environmental variables (THI, wind speed, solar intensity) and milk constituents no notable correlation were recorded in the present study. But highly significant $(\mathrm{P}<0.01)$ positive correlation was observed between protein and SNF ( $r=.986)$, lactose and SNF ( $r=.993)$, salt and SNF $(r=.898)$ lactose and protein $(r=.984)$, salt and protein $(r=.901)$ and salt and lactose $(r=.901)$. Bharucha (2019) reported non-significant positive correlation for milk fat and SNF. Whereas, milk proteins and lactose concentrations were also non significantly but negatively correlated with each other, which is contradictory to the findings of the present study.

The environmental variables (DbT, WbT, wind speed, solar intensity and THI) during three seasons are presented in Table 3. It is observed that, the mean $\mathrm{WbT}$ and wind speed were significantly $(\mathrm{P}<0.05)$ higher in monsoon and winter, respectively. Whereas, DbT temperature, solar intensity and THI were significantly $(\mathrm{P}<0.05)$ higher in summer season as compared to other seasons. Although the DbT temperature and THI during summer was highest (84.98) as compare to winter (79.33) and monsoon (81.61) but it was still moderate. This might be the reason for non significant variation in milk constituents during our study. Also the native animals are very well adapted to local conditions and spend minimum comparatively lesser energy for thermoregulation. Although, there were variation in DbT, WS and THI amongst different seasons, it failed to evoke any measurable stress, which resulted into lack of difference for various milk constituents in Marathwadi buffaloes.

\section{Acknowledgement}

Authors sincerely extend their gratitude to Associate Dean, College of Veterinary and Animal Sciences (MAFSU), Parbhani, Department of Biotechnology, India and Director of Research, MAFSU, Nagpur for all the facilities made available for the study

\section{References}

Bahiram K. B., Khan, J. R., Gade, N. E., Gendley, M. K., Patil, M. S. and Kumarsamy, J. 2020. Studies on Milk Yield, Milk Composition, Circulating Hormones, Energy Metabolites and Biochemical Parameters during Complete Lactation in Sahiwal Cows.Int. J. Curr. Microbiol. App. Sci 9 (9): 1586-1599.

Balusami, C. 2015. Milk constituents of non-descript and graded Murrah buffaloes in Tamil Nadu, India. Indian Journal of Natural Sciences, 5(28): 2475 - 2705.

Bharucha, S. V. 2019. Effect of THI on hormone profile, blood metabolites, milk composition and BCS in lactating Murrah buffaloes. Ph.D Thesis submitted to Maharashtra Animal and Fishery Sciences University, Nagpur, India.

Cheruiyot, E. K., Bett, R. C., Amimo, J. O. and Mujibi F. D. N. 2018. Milk composition for admixed dairy cattle in Tanzania. Front. Genet., 9(142): $1-12$.

Claeys, W. L., Verraes, C., Cardoen, S., Block, J. D., Huyghebaert, A., Raes, K., Dewettinck, K. and Herman L. 2014. Consumption of raw or heated milk from different species: An evaluation of the nutritional and potential health benefits. 
Food Control, 42: $188-201$.

Cinar, M., Serbester, U., Ceyhan, A. and Gorgulu, M. 2015. Effect of somatic cell count on milk yield and composition of first and second lactation dairy cows. Ital. J. Anim. Sci., 14(1): $105-108$.

Çinar, M. U., Ozsoy, T., Beyzi, S. B., Kaliber, M. and Konca, Y. 2019. Milk and fatty acid composition of Anatolian water buffalo (Bubalus bubalis) from different provinces. Buffalo Bulletin 38(1): $107-118$.

Garkal, R. A. and Kekan, P. M. 2014. Effect of different housing systems on biochemical parameters in buffaloes during winter season. Ind. Jour. Field Veterinarians, 10 (2): 80-81.

Harris, B. and Bachman K. C. 2002. Nutritional and management factors affecting solids-not-fat, acidity and freezing point of milk. Cooperative Extension Service, Institute of Food and Agricultural Sciences, University of Florida. Publication number DS25.

Haque, N., Hossain, S. K. A. and Singh M. 2017. Effect of management practices on milk yield and composition of lactating Murrah buffaloes during different seasons. Bull. Env. Pharmacol. Life Sci., 6(3): 447 - 450.

Kekan, P. M., Garkal, R. A., Kharde, S. D., Narladkar B. W. and Munde V. K. 2016. Effect of seasonal variations and different housing systems on physiological responses and hematological parameters of buffaloes. Ind. Jour. Anim. Sci. 86 (7): 758-761.

Macedo, P. M., Wechsler, F. D., Ramos, A. A., Amaral, J. B., Souza, J. C., Resende, F. D. and Oliveira, J. V. 2001. Physicochemical composition and milk production of Mediterranean buffaloes in western São Paulo State. Rev. Bras. Zootec., 30(3): 1084 - 1088.

MCDowell R.E. 1972. Improvement of Livestock Production in Warm Climate. San Francisco. W.H. Freeman and Co.

Meena, H. R., Ram H. and Rasool, T. J. 2007. Milk constituents in non-descript buffaloes reared at high altitudes in the Kumaon hills of the central Himalayas. Buffalo Bull., 26: 72 - 76.
Mushtaq, A. 2009. Effect of physiological states on milk fatty acids profile in dairy cows and buffaloes. Ph.D. thesis submitted to the N.W.F.P Agricultural University, Peshawar.

Patbandha, T. K., Ravikala, K., B. Maharana, R., Marandi, S., Ahlawat, A. R. and Gajbhiye P. U. 2015. Effect of season and stage of lactation on milk components of Jaffrabadi buffaloes. The Bioscan 10(2): 635 - 638.

Pawar, H. N., Ravi Kumar, G. V. P. P. S. and Narang, R. 2013. Effect of heat stress on milk production and composition in Murrah buffaloes. J. Buffalo Sci., 2: 98 - 102.

Pollott, G. E. 2004. Deconstructing milk yield and composition during lactation using biologically based lactation models. J. Dairy Sci., 87: 2375 $-2387$.

Sales, D. C., do N. Rangel, A. H., Urbanod, S. A., Todnhatio, H., Júnioodr, J. G. B. G., Uiolhermionod, M. M., Aguioar, E. M., Bezerra, M. de F. 2018. Buffalo milk composition, processing factors, whey constituents recovery and yield in manufacturing Mozzarella cheese. Food Sci. Technol, Campinas, 38(2): 328 - 334.

Sodi, S. S., Mehra, M. L., Jain, A. K. and Trehan, P. K. 2008. Effect of non-genetic factors on the composition of milk of Murrah buffaloes. Indian Vet. J., 85: 950 - 952.

SPSS Inc. 1997. SPSS (Statistical Package for Social Sciences) for Windows $\odot$, (1993), Version 20.00.SPSS Inc., Chicago, IL.

Wankar, A.K., Kekan, P. M., Daware, S. B., Manimaran, S., Bagadhe, P. and Buktare, M.R. 2020. Effect of THI and other environmental variables on milk constituents in red Kandhari cattle and Marathwadi Buffaloes. Journal of Entomology and Zoology Studies, 8(2): 13721376.

Zhou, L., Tang, Q., Iqbal, M. W., Xia, Z., Huang, F., Liang, L. L. M., Lin, B., Qin, G. and Zou, C. 2018. A comparison of milk protein, fat, lactose, total solids and amino acid profiles of three different buffalo breeds in Guangxi, China. Italian Journal of Animal Science, 1 - 6 .

\section{How to cite this article:}

Kekan, P. M., A. K. Wankar, S. B. Daware, Amrutkar, S. A. 2021. Effect of Seasons x Meteorological Variables on Normal Milk Constituents in Marathwadi Buffaloes. Int.J.Curr.Microbiol.App.Sci. 10(02): 388-392. doi: https://doi.org/10.20546/ijcmas.2021.1002.045 